\title{
"The determinants of Islamic governance disclosure: the case of Indonesian Islamic banks"
}

\begin{tabular}{|c|c|}
\hline \multirow{6}{*}{ AUTHORS } & Ahmad Nurkhin (D https://orcid.org/0000-0003-4743-1134 \\
\hline & R https://publons.com/researcher/N-5002-2019 \\
\hline & Agus Wahyudin (D https://orcid.org/0000-0002-8902-0221 \\
\hline & Hasan Mukhibad (D) https://orcid.org/0000-0001-8979-5169 \\
\hline & Fachrurrozie (D https://orcid.org/0000-0003-4561-7461 \\
\hline & Satsya Yoga Baswara \\
\hline ARTICLE INFO & $\begin{array}{l}\text { Ahmad Nurkhin, Agus Wahyudin, Hasan Mukhibad, Fachrurrozie and Satsya } \\
\text { Yoga Baswara (2019). The determinants of Islamic governance disclosure: the } \\
\text { case of Indonesian Islamic banks. Banks and Bank Systems, 14(4), 143-152. } \\
\text { doi:10.21511/bbs.14(4).2019.14 }\end{array}$ \\
\hline DOI & http://dx.doi.org/10.21511/bbs.14(4).2019.14 \\
\hline RELEASED ON & Wednesday, 18 December 2019 \\
\hline RECEIVED ON & Sunday, 27 January 2019 \\
\hline \multirow[t]{2}{*}{ ACCEPTED ON } & Tuesday, 19 November 2019 \\
\hline & $(\mathrm{cc}) \mathrm{EY}$ \\
\hline LICENSE & $\begin{array}{l}\text { This work is licensed under a Creative Commons Attribution } 4.0 \text { International } \\
\text { License }\end{array}$ \\
\hline JOURNAL & "Banks and Bank Systems" \\
\hline ISSN PRINT & $1816-7403$ \\
\hline ISSN ONLINE & $1991-7074$ \\
\hline PUBLISHER & LLC "Consulting Publishing Company "Business Perspectives" \\
\hline FOUNDER & LLC "Consulting Publishing Company "Business Perspectives" \\
\hline
\end{tabular}

NUMBER OF REFERENCES

33
NUMBER OF FIGURES

1
$-=-$
$z=-$

NUMBER OF TABLES

3

(C) The author(s) 2022. This publication is an open access article. 


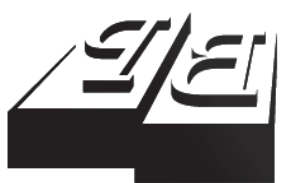

BUSINESS PERSPECTIVES

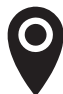

LLC "CPC "Business Perspectives" Hryhorii Skovoroda lane, 10, Sumy, 40022, Ukraine

www.businessperspectives.org

Received on: $27^{\text {th }}$ of January, 2019 Accepted on: 19 $9^{\text {th }}$ of November, 2019

(C) Ahmad Nurkhin, Agus Wahyudin, Hasan Mukhibad, Fachrurrozie, Satsya Yoga Baswara, 2019

Ahmad Nurkhin, Head of the Department, Faculty of Economics, Department of Economic Education (Accounting Education), Universitas Negeri Semarang, Indonesia.

Agus Wahyudin, Dr., Lecturer, Faculty of Economics, Department of Accounting, Universitas Negeri Semarang, Indonesia.

Hasan Mukhibad, M.Si., Lecturer, Faculty of Economics, Department of Accounting, Universitas Negeri Semarang, Indonesia.

Fachrurrozie, M.Si., Lecturer, Faculty of Economics, Department of Accounting, Universitas Negeri Semarang, Indonesia.

Satsya Yoga Baswara, M.Sc., Lecturer, Faculty of Economics, Department of Economic Education (Accounting Education), Universitas Negeri Semarang, Indonesia.

\section{() (1)}

This is an Open Access article, distributed under the terms of the Creative Commons Attribution 4.0 International license, which permits unrestricted re-use, distribution, and reproduction in any medium, provided the original work is properly cited.

Ahmad Nurkhin (Indonesia), Agus Wahyudin (Indonesia), Hasan Mukhibad (Indonesia), Fachrurrozie (Indonesia), Satsya Yoga Baswara (Indonesia)

\title{
THE DETERMINANTS OF ISLAMIC GOVERNANCE DISCLOSURE: THE CASE OF INDONESIAN ISLAMIC BANKS
}

\begin{abstract}
This paper aims to examine the determinants of Islamic Governance Disclosure (IGD) in Islamic banks in Indonesia. The research method used is a quantitative approach involving Islamic commercial banks in Indonesia, where their annual reports can be accessed during the 2011-2018 observation period. The data collection methods used are analysis of documentation and content analysis. Content analysis was used to calculate the IGD index. Path analysis with WarpPLS software was used to analyze data. The results show that the number of members of the Sharia supervisory board had a negative and significant effect on IGD, while leverage, size, and age can influence the IGD positively and significantly. In addition, institutional ownership has a negative and significant effect on IGD. Profitability and composition of the independent board of commissioners do not significantly affect the IGD.
\end{abstract}

\section{Keywords}

JEL Classification

\section{INTRODUCTION}

Banks operating in Indonesia consist of two forms, namely conventional banks and Islamic banks. Islamic Bank is a bank that operates based on Islamic sharia. Islamic banks implement good corporate governance (GCG) in their operations. Some terms are known such as sharia corporate governance or sharia governance (Ginena, 2014; Hasan, 2010; Muneeza \& Hassan, 2014), or Islamic corporate governance (Bhatti \& Bhatti, 2010; Choudhury \& Alam, 2013; Choudhury \& Hoque, 2006; Elghuweel, Ntim, Opong, \& Avison, 2017). Sharia corporate governance is different from conventional GCG and both have unique objectives (Alnasser \& Muhammed, 2012; Muneeza \& Hassan, 2014). In the framework of sharia corporate governance, decision making for companies must be based on shura or consultation (Muneeza \& Hassan, 2014). Hassan (2012) proposed two structures on sharia corporate governance, namely the tawhid and shura based approach and the stakeholder's approach. Hasan (2010) argued that the sharia governance model in Islamic financial institutions does not exist yet.

The GCG implementation for sharia commercial banks in Indonesia includes disclosure in reference to Bank Indonesia Regulation No. 11/33/ PBI/2009 officially implemented on January 1, 2010 (Ardhanareswari, 2017). Ginena (2014) stated that there are at least five (5) models for 
implementing sharia governance systems, namely reactive approach (applied in the UK and Turkey), passive approach (applied in Saudi Arabia), minimalist approach (applied in Bahrain, Dubai and Qatar), pro-active approach (applied in Malaysia), and interventionist approach (applied in Pakistan). Several international institutions issued standards and principles regarding GCG, such as OECD, IFSB, and AAOIFI. AAOIFI adopts Statement on Governance Principles for Islamic Financial Institutions.

The factors that influence the extent of Islamic governance disclosure have not yet been widely studied. Azid and Alnodel (2018) found that industry type, ownership structure, and board composition have a significant effect on the SGD area. While size, leverage, and ROA did not prove to have a significant effect. Albassam and Ntim (2017) found a significant effect of Islamic value disclosure on the level of corporate governance disclosure. They also revealed a significant effect of the audit firm size, board size, government ownership, institutional ownership, and the presence of a GCG committee on the level of voluntary CG disclosure. However, these authors failed to prove the effect of profitability on CG disclosure. Grassa (2018) confirmed that ownership concentration, ROA, leverage, and bank age had a significant effect on CGDI, while size of the bank does not have a significant effect on CGDI.

The results of other studies indicated that the Islamic value index, quality of governance, macroeconomic factors (GDP and inflation) have a positive and significant effect on CGDI (Sarhan \& Ntim, 2018). Also, a significant effect of directors' ownership, company size, company age, and ROA on CGDI was found. Block shareholding, growth opportunities, and leverage do not prove to have a significant effect. Haddad, Sbeiti, and Qasim (2017) stated that company size is the main determinant of CG disclosure, followed by external auditing and liquidity. Abdullah, Percy, and Stewart (2015) found that factors influencing voluntary governance disclosure include the size of Islamic banks, the level of political and civil repression and the legal system.

This study aims to examine the determinants of the Islamic Governance Disclosure in Islamic banks in Indonesia. It focuses on the activities of the Sharia supervisory board (SSB), the performance of zakat, and disclosures on non-halal income. The determinants that are examined influential on IGD are the SSB, profitability, institutional ownership, government ownership, company size, leverage, and company age.

\section{LITERATURE REVIEW}

\subsection{The concept of Islamic governance disclosure}

Agency theory became the basic theory in this study because it is often used as the basis for reviewing good corporate governance (GCG). Agency theory explains that agency relations arise when one or more persons (principal) employ another person (agent) to provide a service and then delegate decision-making authority to the agent (Jensen \& Meckling, 1976). Besides, it is stated that companies that separate management functions from ownership functions will be vulnerable to agency conflicts. The causes of the conflict include decision-making process related to two things, namely:
1) fundraising activities; and

2) deciding how funds are invested.

Agency conflicts, or often referred to as agency problems, can be minimized by a supervisory mechanism that can align these interests so that agency costs arise.

Jensen and Meckling (1976) defined corporate governance as a model or set of rules for institutional practical development to protect investors from managerial opportunistic behavior and entrepreneurial spirit. Corporate governance is a series of mechanisms that can protect minority parties (outside investors/minority shareholders) from exploration carried out by managers and controlling shareholders (insider) with an emphasis on legal mechanisms. Hasan and Butt (2009) 
stated that corporate governance can be interpreted as a philosophy and mechanism related to value creation for shareholders. In this case, corporate governance requires processes and structures that facilitate through the company management in such a way that it can ultimately guarantee the protection of individuals and all stakeholders.

The increasing number of companies that must comply with sharia requires the formation of corporate governance rules in accordance with Islamic law (Muneeza \& Hassan, 2014). The goal is not only to work for profit for shareholders and stakeholders, but also to thank God and to give benefit to the community. Ginena (2014) stated that "... sharia governance is the overall system that manages the conformity of Islamic banks and IFIs to the precepts of sharia pertaining to commercial transactions in all activities". M. Bhatti and M. I. Bhatti (2010) described the Islamic Corporate Governance (ICG) as follows:

ICG seeks to devise ways in which economic agents, the legal system, and corporate governance can be directed by moral and social values based on Sharia laws. Its supporters believe that all economic, corporate, and business activities should be based on an ethnoreligious paradigm, with the sole aim being the welfare of individuals and society as a whole. In many ways, ICG pursues the same objectives as conventional Corporate Governance, but within the religious-based moral codes of Islam. However, there is currently no clear unified understanding of "corporate governance" under Islamic financial law; a model of ICG may be proposed by reconciling the objectives of Sharia laws with the stakeholder model of corporate governance.

Based on the above description, it can be concluded that the Islamic Governance Disclosure (IGD) referred to in this study is the disclosure of the implementation of GCG in Islamic commercial banks based on existing regulations. The dimensions distinguishing between GCG and IGD disclosures are disclosures regarding the existence of sharia supervisory boards, the performance of zakat, non-halal income, and other disclosure dimensions.

Darmadi (2013) tried to reveal GCG practices in Islamic banks in Indonesia. He used the Corporate
Governance Disclosure Index (CGDI) to assess disclosure rates in seven Islamic public banks in Indonesia. Meanwhile Abdullah, Percy, and Stewart (2013) compared sharia disclosures within the framework of the sharia governance system in Islamic banks in Indonesia and Malaysia in 2009. Ardhanareswari (2017) explored two Islamic commercial banks, namely BNI Syariah and BRI Syariah. GCG disclosure focuses on disclosure of GCG principles, which include transparency, accountability, responsibility, independence and fairness and equality.

\subsection{Determinants of Islamic governance disclosure}

The issue of good corporate governance (GCG) remains interesting to explore. GCG is an important instrument, especially in managing business entities. Measurement of GCG also varies in research, including using the proxy mechanism of GCG or GCG index. Many researchers try to reveal the influence of GCG on financial performance or company value (Arora \& Sharma, 2016; Asrori, 2014; Malik \& Makhdoom, 2016; Wahyudin \& Solikhah, 2017). Other researchers tested the correlation of GCG and corporate social responsibility (Said, Joseph, \& Mohd Sidek, 2017).

Gandia (2008), Green and Graham (2015), Hassan (2012), Ntim, Opong, Danbolt, and Thomas (2012), Tsamenyi, EnninfulAdu, and Onumah (2007) conducted reseach on GCG disclosure. Besides examining the extent of disclosure, they also considered factors influencing GCG (Gandia, 2008; Ntim et al., 2012; Tsamenyi et al., 2007). In the context of companies in Indonesia, Djakman, Siregar, and Harahap (2017) tested the practice of GCG disclosure and found that the audit and internal audit committee disclosures were still relatively low in 2012 and 2013.

Tsamenyi et al. (2007) found that ownership structure, dispersion of shareholding, and firm size significantly influence GCG disclosure. Gandia (2008) found that the level of disclosure depends on the level of the company, its age, visibility, and reality related to the information and communication service industry. Ntim et al. (2012) found that block ownership was negatively related to GCG disclosure, while board size, au- 
dit firm size, cross-listing, the existence of CG committees, government ownership and institutional ownership had a positive effect on voluntary CG disclosure.

CG disclosure should be conducted by a company to gain the legitimacy of various parties that the company has fulfilled the applicable responsibilities and regulations. Profitability is one of the factors influencing the level of voluntary disclosure of companies (Islamic governance disclosure). Companies with good profitability tend to disclose important information to the public, including governance disclosure. This is in accordance with agency theory, where CG disclosure is part of the form of corporate management's responsibility towards shareholders. Management seeks to show good performance by carrying out IGD. There are only a few researchers who have proven a significant relationship between profitability with IGD (Grassa, 2018; Sarhan \& Ntim, 2018), while there are those who also fail to prove their relationship (Azid \& Alnodel, 2018; Samaha, Dahawy, Hussainey, \& Stapleton, 2012).

Size and leverage are the next factors influencing IGD. The larger the company size, the wider the CG disclosure. Leverage has a negative influence. The smaller the level of leverage, the wider the IGD will be. Companies that have high debt tend to be more careful in disclosing their information to the public. This is due to company's concern about the influence of information on the decisions of investors and other parties. The empirical test results have found a positive effect of firm size (Abdullah et al., 2015; Haddad et al., 2017; Sarhan \& Ntim, 2018) and leverage (Grassa, 2018) on IGD. There are also researchers who have not succeeded in proving a firm size dependence on IGD (Azid \& Alnodel, 2018; Grassa, 2018) and leverage on IGD (Azid \& Alnodel, 2018; Sarhan \& Ntim, 2018).

The existence of an independent board of commissioners is also predicted to influence the extent of Islamic governance disclosure. This means the higher the presence of independent commissioners, the more Islamic bank will increase IGD. Indrawaty and Wardayati (2016) argue that the composition of the board will influence the implementation of Islamic governance. Azid and
Alnodel (2018) and Albassam and Ntim (2017) found the influence of the board composition on shariah governance disclosure. Ownership structure is also a determinant of IGD (Azid \& Alnodel, 2018; Grassa, 2018). Islamic banks owned by the government tend to be more obedient. The IG disclosure will be even wider. Albassam and Ntim (2017) successfully managed to find a significant effect of government ownership on CG disclosure.

Researchers will also examine the relationship of the Sharia supervisory board to the IGD. The relationship between SSB and IGD is less evident. The existence of SSB will increase the degree of IGD. SSB measurement includes the number of SSB members, SSB education level, attendance rate of SSB member meetings, and other relevant measures. The existence of SSB in Islamic banks is crucial to ensuring that Islamic banks operate in accordance with the rules and teachings of Islam. CG disclosure was also influenced by SSB. The more active the SSB members, the more Islamic banks will tend to express CG well. Sarhan and Ntim (2018) found that the Islamic value index had a positive and significant effect on CGDI.

Based on the description, the research hypotheses are as follows:

H1: SSB has a positive and significant effect on IGD.

H2: Profitability has a positive and significant effect on IGD.

H3: Leverage has a positive and significant effect on IGD.

H4: Size has a positive and significant effect on IGD.

H5: Bank age has a positive and significant effect on IGD.

H6: The composition of independent commissioners has a positive and significant effect on IGD.

H7: Institutional ownership has a positive and significant effect on IGD. 


\section{METHOD}

\subsection{Research population and samples}

This research is a cause-and-effect study to examine the factors influencing Islamic governance disclosure (IGD) in Islamic commercial banks in Indonesia. The population in this study is Islamic commercial banks operating in Indonesia. The sampling method uses purposive sampling method addressed to the banks having the criteria of the availability of an annual report online for eight years of observation (2011 to 2018). There are nine Islamic banks that meet the criteria, namely Muamalat Indonesia Bank, Bank Syariah Mandiri, BNI Syariah, Panin Bank Syariah, BCA Syariah, BRI Syariah, May Bank Syariah, Bukopin Syariah, and Mega Bank Syariah.

\subsection{Operational definition of research variables}

The dependent variable in this study is the IGD in Islamic commercial banks in Indonesia. The dimensions are developed from the study of Abdullah et al. (2013) and Bank Indonesia Regulation No.11/33/PBI/2009. There are four main items in the dimensions of Islamic governance disclosure, namely disclosures regarding SSB, disclosure of SSB reports, disclosure of zakat, and disclosure of non-halal income. The independent variables in this study are the existence of SSB, profitability, institutional ownership, government ownership, company size, leverage, and company age. Table 1 gives the operational definitions of variables.

\subsection{Techniques or data collection and analysis}

Data collection techniques used in this study are documentation and content analysis. Content analysis was developed based on previous research (Abdullah et al., 2013) to measure the disclosure of Islamic governance in Islamic banks in Indonesia. The data analysis method used is path analysis aiming to test the influence of independent variables on IGD. Besides, the WarpPLS 6.0 software was employed.

\section{RESULTS AND DISCUSSION}

\subsection{Results}

Table 2 shows the descriptive statistic of research variables. The mean value of IGD is 0.6468 . It means that Islamic banks in Indonesia have disclosed Islamic governance $64.68 \%$. The score is quite good. The attendance of SSB members for meeting is very good. The score (mean) is 0.9327 or $93.27 \%$. The Islamic banks in Indonesia have two or three SSB members. There is a large deviation in standard value of profitability (ROA

Table 1. Operational definition of research variables

\begin{tabular}{|c|c|c|}
\hline No. & Research variables & Indicators/Operational variables \\
\hline 1 & Islamic governance disclosure & $\begin{array}{l}\text { Disclosure of Sharia Supervisory Board (SSB) } \\
\text { Disclosure of SSB report } \\
\text { Disclosure of zakat } \\
\text { Disclosure of non-halal income }\end{array}$ \\
\hline 2 & Presence of Sharia Supervisory Board & $\begin{array}{l}\text { Number of SSB members } \\
\text { Number of SSB meetings } \\
\text { Level of attendance of SSB members }\end{array}$ \\
\hline 3 & Profitability & ROA (return on assets) and ROE (return on equity) \\
\hline 4 & Leverage & DAR (debt-to-assets ratio) and DER (debt-to-equity ratio) \\
\hline 5 & Company size & Total assets \\
\hline 6 & $\begin{array}{l}\text { The composition of the independent } \\
\text { board of commissioners }\end{array}$ & $\begin{array}{l}\text { Comparing the number of independent board members with the total members of } \\
\text { the board of commissioners }\end{array}$ \\
\hline 7 & Company age & The length of time the bank existed \\
\hline 8 & Institutional ownership & $\begin{array}{l}\text { Comparing the number of shares owned by the institution and the total outstanding } \\
\text { shares }\end{array}$ \\
\hline
\end{tabular}


Table 2. Descriptive statistics

\begin{tabular}{|c|c|c|c|c|}
\hline Variables & Minimum & Maximum & Mean & Std. deviation \\
\hline IGD & 0.44 & 0.86 & 0.6468 & 0.0964 \\
\hline SSB members & 2 & 3 & 2.3099 & 0.4713 \\
\hline SSB meetings & 7 & 27 & 14.1268 & 4.1534 \\
\hline SSB attendance & 0.58 & 1 & 0.9327 & 4.3227 \\
\hline Return on assets & -20.13 & 9.51 & 0.4428 & 4.3227 \\
\hline Return on equity & -94.01 & 57.98 & 4.1739 & 20.9829 \\
\hline Debt-to-assets ratio & 2.8 & 80.98 & 18.4059 & 12.5230 \\
\hline Debt-to-equity ratio & 6.28 & 425.7 & 166.7266 & 108.5071 \\
\hline Assets & 27.22 & 36.5025 & 30.1117 & 1.7217 \\
\hline Age & 1 & 28 & 9.5070 & 7.0304 \\
\hline Independent commissioner board & 0.29 & 1 & 0.6507 & 0.1531 \\
\hline Institutional ownership & 0.44 & 0.86 & 0.6468 & 0.0964 \\
\hline
\end{tabular}

and ROE) and debt (DAR and DER). There is a large percentage of independent commissioner board members, which is $65.07 \%$ on average.

The prerequisite test results using the WarpPLS software are in Table 3. Based on the results of the prerequisite criteria test, hypothesis testing can be conducted because it meets all the criteria.

The results of hypothesis testing are in Figure 1. The results show that SSBMEM (membership of the Sharia supervisory board) has a value of $P=$ 0.02 with a coefficient of -0.23 . This means that the Sharia supervisory board has a significant effect on Islamic governance disclosure (IGD). However, the coefficient value is negative. The SSBMET variable (number of Sharia supervisory board meetings) has a $P$-value $=0.330$ with a coefficient $=-0.051$. This means SSB meetings have no significant effect on IGD. SSBATT (the presence of SSB) has a $P$-value of 0.487 with a coefficient value of -0.004 , which means that the attendance rate of SSB members has no significant effect on IGD.
The profitability variable is measured by two proxies, namely ROA and ROE. Both are not proven to have a significant effect on IGD. It can be seen that the $P$-value of more than 0.005 is 0.239 and 0.153 . While the leverage variable with DER proxy proved to have a significant effect on IGD. The $P$-value of $D E R$ is 0.031 or less than 0.05 with a path coefficient value of 0.025 . The firm size and total assets size variables showed a positive and significant effect on IGD, in which it has $P$ value $<0.001$ with path coefficient 0.602 .

The company age variable (AGE) has a $P$-value $=$ 0.002 with a path coefficient of 0.318 . This shows that the company age has a significant and positive impact on IGD. The INDCOM variable (independent commissioner) has not shown a significant effect on IGD. $P$-value of INDCOM is 0.208 or more than 0.05 . And the INST variable (institutional ownership) has a $P$-value of 0.001 with a coefficient of -0.330 . This means that institutional ownership has a significant effect on IGD.

Table 3. Results of the prerequisite test

\begin{tabular}{|c|c|c|c|}
\hline Items & Criteria & \multicolumn{2}{|c|}{ Test results } \\
\hline Average path coefficient (APC) & $P<0.005$ & $\begin{array}{c}A P C=0.187 \\
P=0.024\end{array}$ & Meets the criteria \\
\hline Average R-squared (ARS) & $P<0.005$ & $\begin{array}{c}A R S=0.840 \\
P<0.001\end{array}$ & Meets the criteria \\
\hline Average adjusted R-squared (AARS) & $P<0.005$ & $\begin{array}{c}A A R S=0.810 \\
P<0.001\end{array}$ & Meets the criteria \\
\hline Average block VIF (AVIF) & Acceptable if $\leq 5$, ideally $\leq 3.3$ & $A V I F=2.751$ & Meets the criteria \\
\hline Average full collinearity VIF (AFVIF) & Acceptable if $\leq 5$, ideally $\leq 3.3$ & $A F V I F=3.111$ & Meets the criteria \\
\hline
\end{tabular}




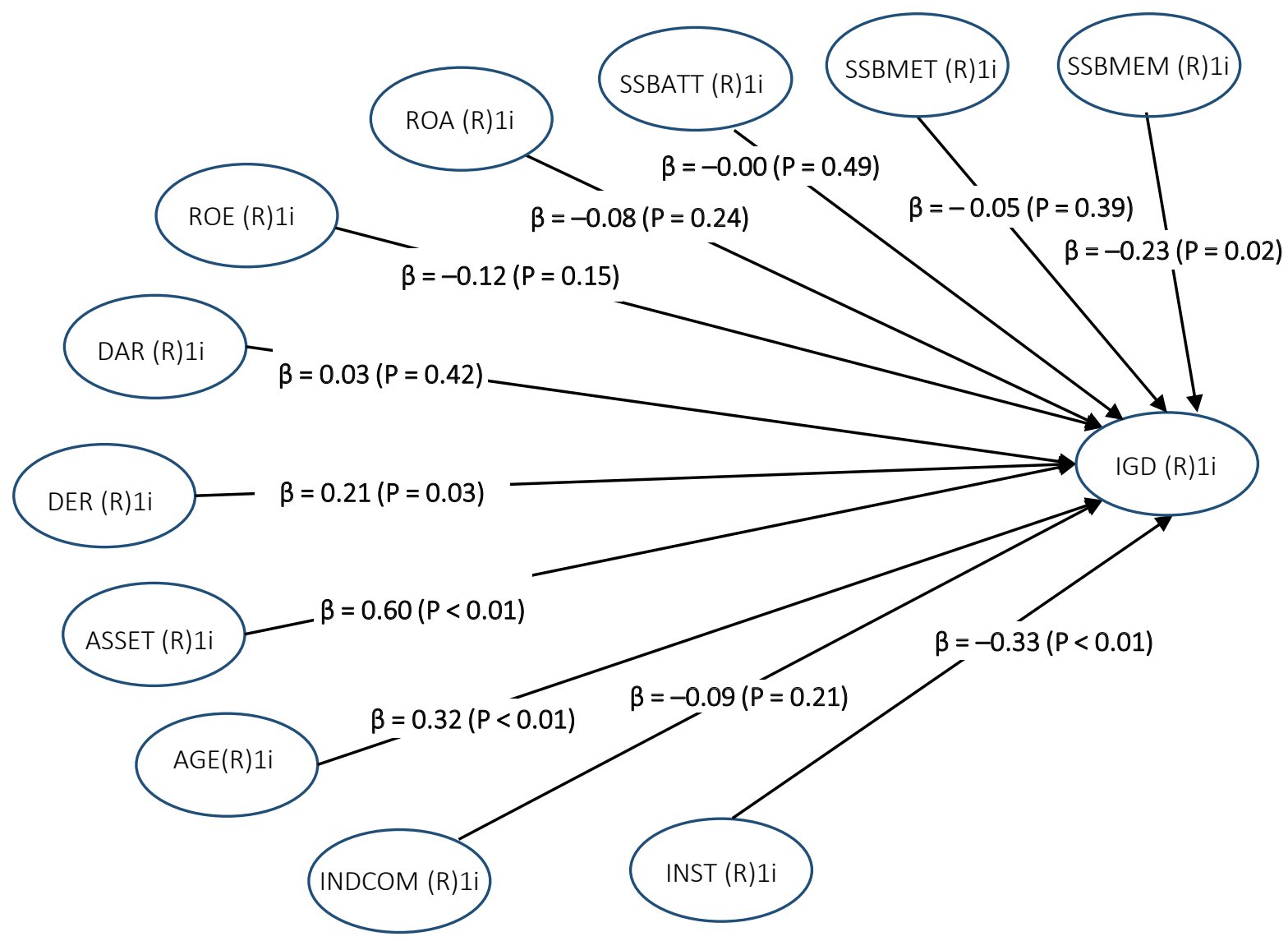

Figure 1. Path analysis

\section{DISCUSSION}

The results showed that leverage with the DER proxy, company size, and company age had a positive and significant effect on IGD. While the existence of a Sharia supervisory board with a proxy for the number of SSB members and institutional ownership proved to have a negative and significant impact on IGD. Other variables were not proven to have a significant effect on IGD.

The existence of the SSB is supposed to have a positive and significant effect on IGD. This means the existence of the SSB will cause the management of the Islamic banks to fully disclose information, including the implementation of corporate governance. In this study, the existence of SSB measured by the number of members proved to be significant but negative. The increasing number of the SSB members actually caused a decline in the index of Islamic governance disclosure. This can be explained by the fact that the number of SSB members is less important than that of its performance. Indrawaty and Wardayati (2016) state that the composition of SSB membership is a determining factor of the Islamic corporate governance. Sarhan and Ntim (2018) found the Islamic value index had a positive and significant effect on CGDI.

Profitability has not been proven to have a significant effect on IGD. Islamic banks have suggested that the Islamic government's disclosure is important to implement. Therefore, it does not depend on the status of the company, whether it could make a profit or not. Research findings supported the previous studies (Azid \& Alnodel, 2018; Samaha et al., 2012). However, there is evidence to suggest that profitability has a positive and significant effect on IGD (Grassa, 2018; Sarhan \& Ntim, 2018).

Leverage is also proven to have a positive and significant effect on IGD. This means the higher the leverage level of Islamic banks, the high- 
er the index of Islamic governance disclosure. The management of Islamic banks wanted to show that they are able to manage the company well despite the high level of leverage. Thus, trust in the bank is maintained. Grassa (2018) and Sharma (2014) have succeeded in finding a significant effect of leverage on governance disclosure. Whereas Azid and Alnodel (2018) and Sarhan and Ntim (2018) found insignificant influence.

The results of the next study indicated that the size of the company has a positive and significant effect on IGD. The level of disclosure of Islamic governance will be higher if Islamic banks have high assets. The bigger the Islamic Bank is, the greater the understanding of the importance of Islamic governance disclosure will be. Research findings confirmed previous results (Abdullah et al., 2015; Haddad et al., 2017; Sarhan \& Ntim, 2018). Further, Sharma (2014) also found a significant relationship between company size and corporate governance disclosure.
Islamic governance disclosure is also influenced by the company age. Like the company size, the longer the Islamic bank is established, the higher the level of Islamic governance disclosure will be. The long-established Islamic banks have gone through many rules and guidelines to implement Islamic governance. Islamic governance disclosure is considered to have a positive impact on the company.

Institutional ownership has a negative and significant effect on IGD. This means the ownership of shares by institutions requires a low level of disclosure of Islamic governance. This could be due to the poor understanding of the importance of Islamic governance disclosure. The disclosure of Islamic governance may not be considered to have a significant effect on the performance of Islamic banks. Therefore, it was not properly implemented. The higher disclosure of Islamic governance allows the more information to be spread openly. This may be a condition avoided by institutional shareholders.

\section{CONCLUSION}

The result showed that the number of sharia supervisory board members, leverage, size, and age had significant and positive impact on IGD. And there is a negative and significant effect of institutional ownership on IGD. The number of meetings and the attendance rate are not able to significantly influence IGD. Meanwhile, profitability has not been proven to have a significant impact on IGD. Debt to equity ratio (DER) was also not proven to have a significant effect on IGD. At least, the composition of the independent board of commissioners also has no significant effect on IGD.

The existence of a Sharia supervisory board is one of the important components in the operation of Islamic banks. SSB can play a role in ensuring the operational activities of Islamic banks in accordance with Sharia (Islamic law). This article argues that the existence of SSB, as measured by the number of SSB members, can significantly affect the disclosure of Islamic governance.

\section{ACKNOWLEDGMENT}

The authors are grateful to the Faculty of Economics of the Universitas Negeri Semarang for their support of research and publication funding. They also thank the editor of the Banks and Bank Systems journal for publication. 


\section{REFERENCES}

1. Abdullah, W. A. W., Percy, M., \& Stewart, J. (2013). Shariah disclosures in Malaysian and Indonesian Islamic banks; the Shariah governance. Journal of Islamic Accounting and Business Research, 4(2), 100-131. https://doi. org/10.1108/JIABR-10-2012-0063

2. Abdullah, W. A. W., Percy, M., \& Stewart, J. (2015). Determinants of voluntary corporate governance disclosure: Evidence from Islamic banks in the Southeast Asian and the Gulf Cooperation Council regions. Journal of Contemporary Accounting \& Economics, 11(3), 262-279. https://doi.org/10.1016/j. jcae.2015.10.001

3. Albassam, W. M., \& Ntim, C. G. (2017). The effect of Islamic values on voluntary corporate governance disclosure The case of Saudi-listed firms. Journal of Islamic Accounting and Business Research, 8(2), 182-202. https://doi. org/10.1108/JIABR-09-2015-0046

4. Alnasser, S. A. S., \& Muhammed, J. (2012). Introduction to corporate governance from Islamic perspective. Humanomics, 28(3), 220-231. https://doi. org/10.1108/08288661211258110

5. Ardhanareswari, R. (2017) Pelaksanaan dan pengungkapan good corporate governance pada bank umum syariah. Jurnal Law and Justice, 2(1), 66-78. https://doi. org/10.23917/laj.v2i1.4338

6. Arora, A., \& Sharma, C. (2016). Corporate Governance and Firm Performance in Developing Countries: Evidence from India. Corporate Governance, 16(2), 420436. https://doi.org/10.1108/CG01-2016-0018

7. Asrori. (2014). Implementasi Islamic corporate governancedan Implikasi terhadap Kinerja Bank Syariah. Jurnal Dinamika Akuntansi, 6(1), 90-102. Retrieved from https://journal.unnes. ac.id/nju/index.php/jda/article/ view/3249/3212

8. Azid, T., \& Alnodel, A. A. (2018). Determinants of Shariah governance disclosure in financial institutions Evidence from Saudi Arabia. International Journal of Ethics and Systems, 35(2), 207-226. https://doi.org/10.1108/IJOES-07-2018-0111

9. Bhatti, M., \& Bhatti, M. I. (2010). Toward Understanding Islamic Corporate Governance Issues in Islamic Finance. Asian Politics and Policy, 2(1), 25-38. https://doi.org/10.1111/j.19430787.2009.01165.x

10. Choudhury, M. A., \& Alam, M. N. (2013). Corporate governance in Islamic perspective. International Journal of Islamic and Middle Eastern Finance and Management, 6(3), 180-199. https://doi.org/10.1108/IMEFM-10-2012-0101

11. Choudhury, M. A., \& Hoque, M. Z. (2006). Corporate governance in Islamic perspective. Corporate Governance, 6(2), 116-128. https://doi. org/10.1108/14720700610655132

12. Darmadi, S. (2013). Corporate governance disclosure in the annual report. Humanomics, 29(1), 4-23. https://doi. org/10.1108/08288661311299295

13. Djakman, C. D., Siregar, S. V., \& Harahap, S. N. (2017). Corporate Governance Disclosure in Indonesia. Pertanika Journal Social Sciences \& Humanities, 25(4), 1739-1752. Retrieved from https://www.researchgate.net/ publication/322558050_Corporate_governance_disclosure_in_ Indonesia

14. Elghuweel, M. I., Ntim, C. G., Opong, K. K., \& Avison, L. (2017). Corporate governance, Islamic governance and earnings management in Oman: A new empirical insights from a behavioural theoretical framework. Journal of Accounting in Emerging Economies, 7(2), 190224. https://doi.org/10.1108/JAEE09-2015-0064

15. Gandia, J. L. (2008). Determinants of internet-based corporate governance disclosure by Spanish listed companies.
Online Information Review, 32(6), 791-817. https://doi. org/10.1108/14684520810923944

16. Ginena, K. (2014). Sharīah risk and corporate governance of Islamic banks. Corporate Governance, 14(1), 86-103. https:// doi.org/10.1108/CG-03-20130038

17. Grassa, R. (2018). Deposits structure, ownership concentration and corporate governance disclosure in GCC Islamic banks: Empirical evidence. Journal of Islamic Accounting and Business Research, 9(4), 587606. https://doi.org/10.1108/ JIABR-10-2014-0034

18. Green, D., \& Graham, C. (2015). Accountability and Independence in Corporate Governance: An Analysis of Board Disclosures in Canada. In Lehman, C., Tinker, T., Merino, B., \& M.Neimark, (Ed.), Corporate Governance: Does Any Size Fit? (pp. 167-193) (Advances in Public Interest Accounting, Vol. 11). Emerald Group Publishing Limited, Bingley. https://doi.org/10.1016/S10417060(05)11008-6

19. Haddad, A. E., Sbeiti, W. M., \& Qasim, A. (2017). Accounting legislation, corporate governance codes and disclosure in Jordan: a review. International Journal of Law and Management, 59(1), 147-176. https://doi.org/10.1108/ IJLMA-07-2016-0064

20. Hasan, A., \& Butt, S. A. (2009). Impact of Ownership Structure and Corporate Governance on Capital Structure of Pakistani Listed Companies. International Journal of Business and Management, 4(2), 50-57. https:// doi.org/10.5539/ijbm.v4n2p50

21. Hasan, Z. (2010). Regulatory Framework of Shariah Governance System in Malaysia, GCC Countries and the UK. Kyoto Bulletin of Islamic Area Studies, 3(2), 82-115. https://doi. org/10.1108/17538391111122195

22. Hassan, M. K. (2012). A disclosure index to measure the extent of 
corporate governance reporting by UAE listed corporations. Journal of Financial Reporting and Accounting, 10(1), 4-33. https://doi. org/10.1108/19852511211237426

23. Indrawaty, \& Wardayati, S. M. (2016). Implementing Islamic Corporate Governance (ICG) and Islamic Social Reporting (ISR) in Islamic Financial Institution (IFI). Procedia - Social and Behavioral Sciences, 219, 338-343. https://doi. org/10.1016/j.sbspro.2016.04.042

24. Jensen, M. C., \& Meckling, W. H. (1976). Theory of the Firm: Managerial Behavior, Agency Costs and Ownership Structure. Journal of Financial Economics, 3(4), 305360.https://doi.org/10.1016/0304405X(76)90026-X

25. Malik, M. S., \& Makhdoom, D. D. (2016). Does corporate governance beget firm performance in Fortune Global 500 companies? Corporate Governance, 16(4), 747-764. https://doi.org/10.1108/CG-122015-0156

26. Muneeza, A., \& Hassan, R. (2014). Shariah corporate governance: the need for a special governance code. Corporate Governance: The International Journal of Business in Society, 14(1), 120-129. https://doi. org/10.1108/CG-02-2011-0015

27. Ntim, C. G., Opong, K. K., Danbolt, J., \& Thomas, D. A. (2012). Voluntary corporate governance disclosures by post-Apartheid South African corporations. Journal of Applied Accounting Research, 13(2), 122-144. https://doi. org/10.1108/09675421211254830

28. Said, R., Joseph, C., \& Mohd Sidek, N. Z. (2017). Corporate Governance and Corporate Social Responsibility (CSR) Disclosure: The Moderating Role of Cultural Values. In Modern Organisational Governance (pp. 189-206). Emerald Publishing Limited. https://doi.org/10.1108/S2043052320170000012013

29. Samaha, K., Dahawy, K., Hussainey, K., \& Stapleton, P. (2012). The extent of corporate governance disclosure its determinants developing market: The case of Egypt. Advances in Accounting, 28(1), 168-178. https://doi.org/10.1016/j.adiac. 2011.12 .00
30. Sarhan, A. A., \& Ntim, C. G. (2018). Firm- and country-level governance compliance and disclosure in MENA countries. Managerial Auditing Journal, 33(6/7), 558-585. https://doi. org/10.1108/MAJ-10-2017-1688

31. Sharma, N. (2014). Extent of corporate governance disclosure by banks and finance companies listed on Nepal Stock Exchange. Advances in Accounting,30(2), 425-439. https://doi.org/10.1016/j. adiac.2014.09.014

32. Tsamenyi, M., Enninful-Adu, E., \& Onumah, J. (2007). Disclosure and corporate governance in developing countries: evidence from Ghana. Managerial Auditing Journal, 22(3), 319-334. https://doi. org/10.1108/02686900710733170

33. Wahyudin, A., \& Solikhah, B. (2017). Corporate Governance Implementation Rating in Indonesia and Its Effects on Financial Performance. Corporate Governance: The International Journal of Business in Society, 17(2), 250-265. https://doi.org/10.1108/ CG-02-2016-0034 